\title{
An Observation on Othering of 65+ Group During the First Phase of Covid-19 Pandemic
}

Application Date: 03.09 .2021

Accepted Date: 25.12.2021 Publishing Date: 30.12 .2021

\author{
Zeynep Genel ${ }^{1}$
}

\author{
Okan University, Faculty of Applied Sciences, \\ Department of Public Relations and Advertising, Istanbul \\ zeynep.genel@okan.edu.tr \\ ORCID: 0000-0002-3140-0053 \\ Batuhan Özuğurlu² \\ Okan University, Faculty of Applied Sciences, \\ Department of Public Relations and Advertising, Istanbul \\ bozugurlu@stu.okan.edu.tr \\ ORCID: 0000-0001-8086-6100
}

\begin{abstract}
With the development of digital media platforms, increasing media consumption has led to many disadvantages as well as indisputable advantages. The effect of increasing social media consumption on the perception of reality and feedback of societies is one of the exacerbated topics of discussion. The Covid19 pandemic has exacerbated these disadvantages by bringing them to the surface of the public sphere and spreading othering, exclusion, and hate speech on various issues. Although the effect of media on hatred discourse is not a new debate of the studies, the inadequacies of news writers in social media literacy and social media users have led to an increase in misinformation, social reactions, and the use of language that alienates some segments of society. One of the groups exposed to this condition during the Covid-19 pandemic in people aged 65+ years group. There were many different claims and misinformation spread about the 65+ years group during the first phase of the Covid-19 break. Within the scope, this study aims to analyze the social othering of groups aged 65+ years group by the influence of news frameworks of news organizations and the sharing of social media users. For this purpose, comments and content shared on Twitter for people aged 65+ years group were collected, and it was aimed to understand what types of news are framed through visual and written language and how this language is effective in sharing social media users. In the context of this study, it was observed that the content led to the exclusion of people aged 65 and over was shared and that there was an impact of the media on these contents. The study aims to contribute to the Covid-19 period by providing a qualitative observation in terms of both health communication and ageism studies. In this scope Twitter hashtags followed by the help of Maxqda and the tweets classified into three groups by analyzing the visual and textual coding of users. As a result, it is observed that blaming, denouncing, and joking frames were reproduced and shared by social media users which consist of visual posts of media accounts.
\end{abstract}

Keywords: Social media, othering, Covid-19, Twitter, ageism.

\footnotetext{
${ }^{1}$ Assistant Professor

2 Specialist
} 


\section{Covid-19'un Illk Döneminde 65+ Yaş Grubunun Ötekileştirilmesi Üzerine Bir İnceleme}

Başvuru Tarihi: 03.09.2021 Yayın Kabul Tarihi: $\quad$ 25.12.2021 Yayınlanma Tarihi: $\quad 30.12 .2021$
Zeynep Genel ${ }^{3}$

Okan Üniversitesi, Uygulamalı Bilimler Fakültesi, Halkla ilişskiler ve Reklamcılık Bölümü, İstanbul

zeynep.genel@okan.edu.tr

iD ORCID: 0000-0002-3140-0053

\section{Batuhan Özuğurlu ${ }^{4}$}

Okan Üniversitesi, Uygulamalı Bilimler Fakültesi, Halkla ilişsiler ve Reklamcılık Bölümü, İstanbul bozugurlu@stu.okan.edu.tr

(iD) ORCID: 0000-0001-8086-6100

\section{Öz}

Dijital medya platformlarının gelişmesiyle artan medya tüketimi, tartışmasız avantajlarının yanısıra birçok dezavantaja da yol açmıştır. Artan sosyal medya tüketiminin, toplumların gerçeklik algısı ve geribildirimlerini ne şekilde etkilediği şiddetlenen tartışma konularından biridir. Covid-19 salgını bu dezavantajların şiddetlenerek kamusal alanın yüzeyine çıkmasına ve çeşitli konularda ötekileştirmenin yayılmasına yol açmıştır. Medyanın ötekileştirmedeki etkisi yeni bir tartışma olmasa da haber hazırlayanların sosyal medya okuryazarlığındaki yetersizlikler, sosyal medya kullanıcıları mezenformasyonun, sosyal tepkilerin ve toplumun bazı kesimlerini ötekileştiren dil kullanımının artışına yol açmıştır. Covid-19 salgını döneminde bu duruma maruz kalan gruplardan biri ise 65 yaş ve üzeri kişilerdir. Covid-19 felaketi ile birlikte 65 yaşa ve üzeri gruplara yönelik bir çok iddia ve kirli bilgi yayılmıştır. Bu doğrultuda bu çalışmanın amacı, haber kuruluşların haber çerçeveleri ve sosyal medya kullanıcılarının paylaşımlarının etkisiyle 65 yaş ve üzeri grupların ötekileştirilmesini analiz etmektir. Bu amaçla, 65 yaş ve üzeri kişilere yönelik Twitter üzerinden paylaşılan yorum ve içerikler toplanarak, görsel ve yazılı dil üzerinden ne tip haberlerin çerçevelendiği ve sosyal medya kullanıcılarının paylaşımlarında bu dilin nasıl etkili olduğunun anlaşılması hedeflenmiştir. Çalışma kapsamında, 65 yaş ve üzeri kişilerin dışlanmasına yol açan içeriklerin paylaşıldığı ve bu içeriklerde medyanın etkisi olduğu gözlemlenmiştir. Çalışma, Covid-19 dönemine gerek iletişim gerekse yaşcılık çalışmaları açısından bir nitel gözlem sunarak katkıda bulunmayı amaçlamaktadır. Bu kapsamda Maxqda yardımıla Twitter hashtagleri ve kullanıcıların görsel ve metinsel kodlamaları takip edilerek, analiz edilmiş ve tweetler üç tema altında analiz edilmiştir. Sonuç olarak medya hesaplarının görsel paylaşımlarından oluşan suçlama, suçlama ve şaka çerçevelerinin yeniden üretildiği ve sosyal medya kullanıcıları tarafından paylaşıldığı gözlemlenmiştir.

Anahtar Kelimeler: Sosyal medya, ötekileştirme, Covid-19, Twitter, yaş̧̧ılık.

3 Doktor Öğretim Üyesi

4 Uzman 


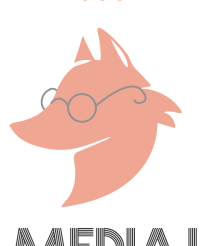

\section{INTRODUCTION}

Social media, the dominant information channel of today and the most dominant influencer of public opinion brought many advantages as simplicity to keep in touch with others, obtain a variety of information with one click, and to discuss the common issues for having an opinion about the agenda of the world. Especially during the pandemic period, it has provided great convenience to maintain our communication with others and help to get news around the world. Along with its advantages, it caused many disadvantages that harm social life frequently. Social media always keep the distance between individuals close. In this way, "The distance becomes meaningless; the ambiguity of the boundaries between far and near brings about a process of identifying and objectivating" (Turan, 2017: 129). Due to that reason, many researchers have been studying its disadvantages in scope of its habitat and user habits. The most complicated problem of the communication universe is the mal forms of information that diffused by social networks. Many issues had shown us that reliable information spread slower than false information, and communication without any intent and consciousness results misinformation (Rodrigez, Leskovec and Schölkopf, 2013; Vosoughi, Roy and Aral, 2018; Geldenhuys, 2020). This made uncertainty about the resources and information as World Health Organization called as misinformation. According to United Nations Educational Scientific and Cultural Organization [UNESCO] (2018) "Misinformation is generally used to refer to misleading information created or disseminated without manipulative or malicious intent" (7). While many authorities have been trying to find a solution to cope with misinformation, the pandemic provided an appropriate predisposing area for the infodemic. Media, one of the pioneering parts of the crucial layer of the public sphere is among the most impactful information source, discussion arena and decision layer of public opinion. We witnessed the dominant role of media platforms in framing public perception and attitude during the Covid-19 pandemic, and as a consequence, misinformation caused to drive a hegemonic mislead discussion (Stjernsward and Glasdam, 2021). Like other areas, disinformation and the pace of social wisdom have harmful effects on health issues, too. In many respects, when the media frames some issues from its perspective, it may affect users negatively and lead a misinformation storm that may incite to other some groups of society on various issues. It may negatively affect members of society, and even cause them to be stigmatized in their social spheres. Derrida describes others as a group that has different characteristics, attitudes or responsibilities, and points the importance of the environment on sociology (cited in Bretz, 2016). For a sustainable public space, equality is essential. A study conducted in 2016 shows that social stigma about epilepsy and misinformation is related to each other. According to this research, even many patient relatives do not have enough knowledge about the disease, they shame of the disease by the negative attitudes of misinformed society (Herrmann, Welter, Berg, Perzynsyi, Doren and Savatovic, 2016). But, in a crisis's moment as a pandemic, it leads to the othering of disadvantaged groups and may be effective on their phycological resilience and health protection decisions negatively. Therefore, the media discourse shapes the public debate. In the Habermasian approach, the discourse should produce mass participation and coalition. The primary reason for occurring in a public sphere is to represent the views of the opinions of the majority. Never mind, the discourse that emerges because of the relations of emerging interest in media and the public-private sphere is placed by taking advantage of the influence of media in the individuals' daily. So, it forces a dominant tendency in the last layer of public space towards the constructed reality (Arendt, 


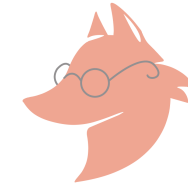

2016). In extension to the dominant role of interest groups, it embodied this layer of the sphere. Temporary realities influence the third layer, which is called the communicative layer, which refers to the echo of public opinion (Sundin, 2015). The third layer represents the communicative process itself; "The symbolic exchange of meanings with an emphasis on reasons to consensus occurs on this level" (Widdersheim, 2017:15). The third layer is the part where the public debates occur: the area of the consensus among the public groups took the decisions through common benefit. Krippendorf (1989) underlines, the mass media with its ideological dominancy on communication has a dominant impact on the social community, communication problems may occur like misinformation or miscommunication what leads the popularity to exclude the differences from the public sphere. Language usage in visual or textual coding is a provocative title of media (Johnson and Enslinn, 2007). As a consequence of media language misinformation may flow, the media portray may cave othering of some group of society. It sometimes relies on low media literacy, while some rely on the political economy of media. For instance, shaping communicative-layer about religion by New York Times frames creates a conflict between North and West. Silva's (2016) study on othering frames of The New York Times, based on religion, showed the media frame had a robust complexion approaching the communicative layer.

Othering has been discussed by many researchers in media studies (Brren, Haynes, Devereux, 2006; Silva, 2016). So, each transformation of the media landscape leads the discussions of the medium. According to Habermas (2007), society should think of living together with the individuals as tagged as others, and the media frame is the key determiner of the logic of othering. The inclusivity of communicative-layer is the sensitive factor to sustain a democratic public sphere. With the increasing popularity of social media, researchers criticize the adverse effects of usage and struggle to urge authorities about its consequences. It is called onlineothering by researchers. Online othering "is means of analysing and making sense of the myriad behaviours, conversations, discourses, which seek to re-draw boundaries in, around and between virtual spaces, and which shapes the rules and norms, which individuals and groups endowed with status and legitimated taking part in these spaces, and those who are not" (Harmer and Lumsden, 2019:2). Southern and Harmer (2019) focused on online-othering behaviours on Twitter about ableism and racism towards women. Familiarity with Southern and Harmer studies, Ozsungur (2021) token a picture from Turkey about online othering of women. So, many of them touched on the relationship between media discourse and misinformation that shapes digital. This makes us think about the relation between information and power.

The Foucauldian approach relies on the reaction that leads to othering a group of knowledge and power. Yet, in the present instance of Foucault, the knowledge that is formed by meaning because of social interaction leads othering. In Foucault's eyes, the interaction of knowledge in society caves the way of reaction as it had during the first time of Covid-19. Because the meaning determines the social practices. It relies on fear, but not on knowledge, just depends on the misknowledge, or we might say it depends on the global knowledge and uncertainty. When knowledge begins with the media interaction, it transforms into misinformation. Foucauldian Social Gerontology refers to the relationship of social practices and knowledge that points to social knowledge as a determiner of power (Foucault, 1980). The hegemonic knowledge that creates social practice may lead to the biases that drive othering as a social practice. This 
sometimes may generate a snowball effect in social discourse and reaction.

We witnessed the social reaction against to $65+$ years group during the first phase of pandemic. It had started with news corporation's false explication of an official resource than spread quickly on the social media. Like many other countries, the $65+$ years group face with a negative social reaction via some social media users in Turkey until the early days of April 2020. Twitter, one of the main news channels of users had dominated the othering discourse against $65+$ years group during those days. In this scope the paper aims to understand how news visual and textual framing affects the audiences' perception and how this discourse as the main resource reproduced by social media users effects this reaction. For these aims, Twitter hashtags were followed between 13 March 2020 to 20 March 2020 and data gathered by the help of Maxqda software. First, the tweets of news accounts and users are classified and then the data remains the criteria: nonym accounts with original context, nonym accounts with reproduction of a pretweet, nonym accounts in hyper-text bellowed a new media sharing, and news media tweets. The studies in similar scope in the literature representing the same period in other countries, and without a theoretical foundation on othering (Wiles, Williams and Gott, 2020: Koskinen, Salminen and Leino-Kilpi, 2020; Sotomayor, Moreno and Celis, 2020) are used as an inspiring foundation. But, theoretical approaches about othering are mentioned in the introduction part for giving the inspiration to further studies. The paper aims to contribute to health communication and new media research area with a case study about Covid-19 in Turkey. The most important goal of the paper is to provoke researchers to focus on communication studies on ageism.

\section{BACKGROUND OF THE STUDY}

The first novel coronavirus case is declared by Turkish Health Minister on 10 March 2020, and accordingly, national emergency announced to cope with the disease. The Cov-Sars2 virus firstly allegedly evolved in China in December 2019: 5,593,631 confirmed cases of COVID-19 within over 353,334 deaths globally by May 28, 2020 (World Health Organization [WHO],2020:129). Within the outbreak of infection, the healthcare system has been strained in almost all countries; brought challenges to provide respiratory system therapies. The first data from Italy and America, where Covid-19 spread rapidly afterward China, showed that the risk of death was high among those over 65 years groups. By the early Chinese studies claimed that the disease harms the elderly most (especially 65+ years group); the rapid spread of this information on the media in an uncontrolled way created some ethical problems (Li, Guan, Wu et. al., 2020). Many governments around the world highlighted age risk in a familiar discourse, thus a communication environment that lays the groundwork for ageism and othering older group is created (Altın, 2020). By the dominancy of this type of official resources, news media and entertainment programs from Washington Post to Hürriyet used mistaken framings due to inefficient health communication knowledge. Additionally, the data were not supporting these claims about $65+$ group (Arun, 2021). After mainstream media focusing on harmful effects and age relationship of the disease on their programmes, misinformation flood about older groups had started over the social media networks, too. The focus of case data on ageism in framings caused the diffusion of 65 age tags on social media that points this group as reluctant and irresponsible to fight with pandemic. Therefore, it is observed that the dominant discourse 


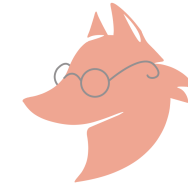

caused othering of elder groups among the society. So, some older groups were excluded from their social media spheres with the effect of media frame in many countries, and afterwards (Gannon, Glover and Abel, 2004; Ellis, 2008), negative stereotypes focused on diffusion of hurtful messages about the older people on social media (Sotomayor, Moreno and Celis, 2020). It is obviously observed, following strategy to provoke others caused excluded of elder groups from the public spheres. This study aims to explain the relationship between news platforms' context and social media users' context in terms of coding and recoding the language. In this scope, a qualitative purposive method is applied to collected sample in March 2020 via Twitter. In the following part, the purpose of analyse and findings are given with a thematic method.

\section{A Snapshot of Othering in Scope of Social Misbeliefs}

Communication studies in the health area became the main topic of public health politics in the present century. Like Butler's scope, health problems are social problems and should be considered from the perspective of social phenomena. Russian Jewish immigrants blamed to infect New York city during 1982 typhus fever and cholera epidemics (Markel, 1997). Additionally, some sort of diseases as mental illness, epilepsy, disabilities are already a social phenomenon of health communication studies because of the common opinion. As a result, communication presents a discipline for transferring and perceiving health information. This perspective had shown us, othering is a kind of collective habit of societies against some sort of patients as Acute Immune Deficiency Syndrome [AIDS], Diabetes Mellitus with injection [IV] treatments, mental health patients and the children with IV form endocrinological therapies (United Nations Aids Programme [UNAIDS], 2003; Public Health Agency of Canada, 2012; Ezell, Walters, Friedman, Bolinski, Jenkins, Schnieder, Link and Po, 2021). Among these studies, some discuss how media discourse caused these patients to marginalized, even stigmatized by society (Creel, Rimal, Mkandawire, Böse and Brown, 2011; Person, Sy, Holton, Govert, Liang, Garza, Gould, Hickson, McDonald, Meijer, Smith, Veto, Williams, Zauderer and National Center of Infectious Disease [NCIDSARS]).

Media discourse plays a significant role in the period of othering of some groups of society by formatting public opinion. Pandemics are more convenient times that increases social stigma, discrimination and othering of different public members. Researches and studies on different pandemics such as La Grippe, SARS and AIDS show the tragic situation and reasons of discrimination of different ethnic groups and researches about Covid-19 show other groups Wiles, Williams and Gott, 2020: Koskinen, Salminen and Leino-Kilpi, 2020; Sotomayor, Moreno and Celis, 2020). As a result of Creel, et.al. study (2011), a radio programme causes the patients to face four type of stigma "Fear of casual contact, shame, blame and judgement and willing to disclose HIV status" (p. 456). In scope of this research, a group of HIV patient who are the audience of a popular radio program and a control group who never followed the program before were tested. The researcher discussed with the control group about the discourses of this radio program. As a result of the study, it is understood that the fear of contact with a HIV patient among the audiences of the program is meaningful which shows that the language of program is effective on social judgements. Alike, Person et. al. (2004), put forward the effect of mainstream media framing on the stigmatization of Asians in their daily lives during the Severe Acute Respiratory Syndrome [SARS] outbreak. Some studies were conducted to show the role of media 
during pandemics and epidemics to provide epistemological models (Collinson \& Heffernan,2014; Reintjes, Das, Klemm, Richardus, Kessler \& Ahmad, 2016). Some other studies showed the linguistic stigmatization of older people by Twitter hashtags during the pandemic (Meiser,2020). Due to misinformation it can said that false information that started to diffuse by main media than spread on the social media built a type of negative illusion. The illusion may create a bias and it may cause sterotypes. Lippmann (1922) describes sterotypes as an image of a group on our mind. Some others grounded othering on attribution what is created by biases. Especially, Heider (1958) highlights attributions and reactions towards a disease that depends on perceptional information. According to Fiske (2005) "Viewing favourable group differences as stable and unfavorable ones unstable" (40) that leads othering unstable group out of the society because of a perception error.

We witnessed that ethnic discrimination against Asian people by the first hybrid media adverse effect during the Covid-19 pandemic. Many news corporations announced the virus in a relationship with Chinese and Far-East countries. It showed how the framing way of news media is seriously triggering the misinformation over social media. Many of this news was shared quickly on social media and reproduced in several discourses what might damage some members of the society. This is not the first misinformation effect of media during global health issues, but rather a recurring situation. According to a study conducted in 2016, due to wrong media and social media frame in the second wave of the H1N1 pandemic, vaccine precaution is ignored by a proportion of the population around Europe, there is a parallel curve with media attention and vaccine curves (Reintjes, et.al, 2016). Turkey is a country with an 81 million population and $\% 75,3$ of the society have an internet connection, which means, people kill 4 hours a day on the Internet (We are Social, 2020). During this period, many reposts and comments blame Chinese society globally. Some influencers and popular media authorities claim that the virus cannot spread in Turkey due to eating and living habits. These claims may provoke many negative posts on Twitter, Facebook and Instagram of which were including hurtful messages. Attacks towards ethnicity have been followed by attacks on older age groups Worldwide, so, hurtful messages distributed on social media. United Nations The impact of Covid-19 on Older Persons Policy Brief put attention the importance of media on framing social stigma, and highlights "It is worrying that remarks and hate speech targeting older persons have emerged in public discourse and on social media as expressions of inter-generational resentment" (United Nations, 2020, p.9).

Sotomayor, Moreno and Celis examined the effect of social media on othering older groups in Mexico during the Covid-19 pandemic for showing the harmful impact of social media manipulation in social life (2020). The United Nations (UN) report shows the impact of Covid-19 on the older years groups, points out the negative role of social media; discusses the solutions. The researches show that ageism was about \%15 before covid-19 (Buz, 2015). But a study conducted in Italy on Twitter comments had shown that it split over to \%21 during the first era of the pandemic (Altın, 2020). The study of Yale University revealed that "Ageism could lead to $\$ 63$ billion in additional annual healthcare costs in the U.S" (cited by Newberry, 1 May, 2020, parag 3 ). Therefore, the aim of this analyze is to understand how present side effects progressed in Turkey. The purpose of analysis is to understand the chain impact of media on society members in terms of disinformation during the Covid-19 pandemic. 


\section{MEDIA』}

\section{THE PURPOSE OF THE ANALYSIS}

The Turkish National Statistical Foundation (TÜIK) 2019 data reveals that 60 years and older groups generate $\% 21,9$ of all population (TÜiK, 2019) and \%92 of this population in metropoles have an internet connection and mobile phone. Additionally, \%95 of this population have two or three social media accounts. \%43 of internet users in Turkey, follows news via digital platforms (Baranseli, Kaya and Şen, 2016). As it is seen on the given data, digital channels and social media networks are pioneering channels for Turkish society, and most elder groups also active internet users. However, a study conducted by Turkish National Broadcasting Academy on habits of Turkish society during the Covid-19 crisis showed that \%51 of Turkish society shares the attractive information by digital channels, even they do not trust the truthiness of the information (Geçer, 2020). Twitter was selected as a research field to collect data, but the visual materials are tracked on the news media over the Twitter accounts after observing most used official news on users' tweets. According to the Digital 2020 report, Turkey with 13,6 million active Twitter users is the sixth country in the World (We are Social, 2020). Therefore, we collect Twitter posts by using social monitoring tool of Maxqda, and particularly thematically analyse the reflections of these posts on othering of $65+$ years group. The study is based on an exploring qualitative approach, it does not refer any qualitative measure. Due to that reason as it is adviced on the research literature (Creswell, 2006) ageism studies mostly use exploring research to understand a social phenomena or a procees (Kross and Guist, 2019). Therefore, the research purpose statement is given except for research questions.

Based on all this information, the analyse purpose statement is to understand the phenomena of how mainstream media probably caused a visual and textual meaning that leads othering of $65+$ years group on society and what kind of meanings diffused on social networks during the first phase of Pandemic in Turkey. For that purpose, the paper hopes to contribute both Covid19 , health communication and ageism studies in the perspective of Turkey with a content aligned observation.

\section{The Scope of the Method}

The internet and social media usage dramatically increased in the world by pandemic, and $\% 44$ of users follow official news media accounts to update coronavirus information (GlobalWeblndex, 2020). Today, the content and agenda do not depend on just a few tv cameras; everyone with a social media account has the power to affect the daily issues. (Film Media Group, 2019). Twitter is one of the most popular social networks in Turkey, and it has a dominancy in determining public perception. Tosun's study (2013) about the role of Twitter on agenda-setting in Turkey put the importance of mainstream media news. Because \%12 of mainstream media news are feet by Twitter content. Özdemir's (2019) research on the news frames shows that Hürriyet, the most popular mainstream news corporation in Turkey, get inspired by the Twitter trend topics \%3,3 in weekly. It is clear that it is not just a bunch of tools to express people's ideas freely, but also it may disseminate public perception and cause negative false social realities.

The selected period represents ten days after the World Health Organization announced Covid- 


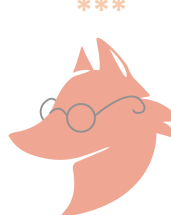

19 as a global pandemic and the first Covid-19 case declared by the Turkish Health Ministry via media. In the light of these perspective, most frequently used hashtags related to the topic classified with the help of Maxqda, which spread over the Twitter among these days are showed on Figure1. Among these hashtags, the hashtags: \#65yaş (\#65year-old), \#65yaş üstü sokağa çıkma yasağı (65+ year-old curfew), \# 65yas (\#65-year-old without a dotty "s") followed between 13 March to 21 March 2020 were followed with Maxqda. The others were not followed due to the limited capacity of the monitoring account.

\section{Fiqure 1. Most frequently hashtags on the topic}

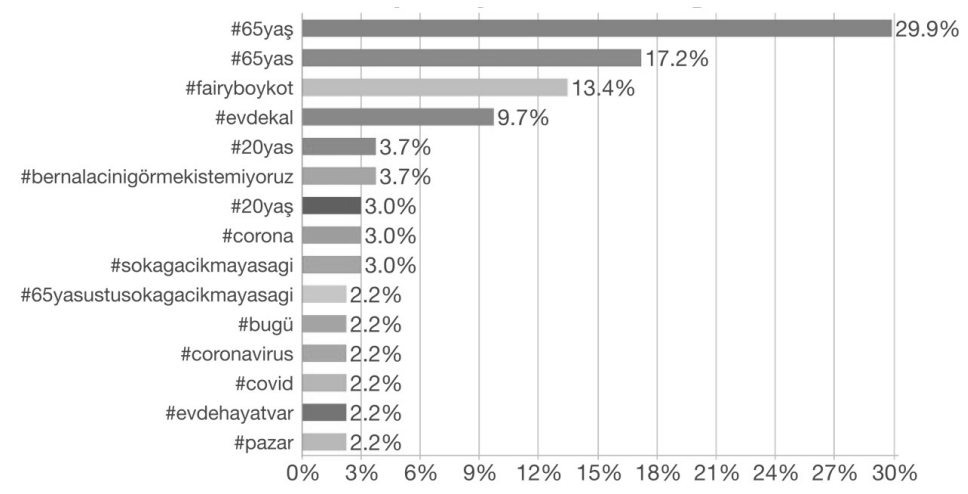

1365 tweets and retweets sellected in total; anonymous accounts' tweets, repeating tweets, and retweets without user's reproduction were excluded from the sample. Purposive sampling method is used to classify the secondary data for cleaning repeating or unrealted sharings. The study also refers a secondary data analysis due to that reason it used a narrowing theming (thematic) approach to observe the visual and textual language. The thematic analyse is used to observe main themes and meanings among the posts. The given quantified numbers in the analyze part aim to shift just an inspiring perspective for potential further quantitative researches. Due to that reason the quantified numbers have no representable skill of overall reflections.

\section{Limitations and Further Directions}

First, the study presents a qualitative secondary analysis; therefore, it does not present any primary analysis what can just open a window to understand how much it is valid on the whole public sphere. Secondarily, the sample is limited in terms of purposive sampling as a sampling technique without the skill of representation of all population's perception. Lastly, the study is not based on a theoretical perspective. The reasons are: 1) most of the studies on thesetopic around the world analyzed without based on a theoritical foundation for observing the shape of social phenomena, 2 ) it is a real time observation and analyze due to limited allowence of Twitter data, 3) limited space to relay the findings 4) the questions were not grounded on any theory because of uncertainity. But, it can open a new perspective to dive deeper of semantical layer of this type of data for further studies, the findings can be inspiring for a theoritical review study. Additionally, the sample technique is purposive and qualitative; due to that reason it refers insights to qualitative perspective, as well as no quantitative meaning. The examples transform 
anonymous formats to provide the ethical standards.

\section{FINDINGS}

During the first phase of Covid-19 declaration in Turkey, the hashtags about $65+$ groups and their risks had started to diffuse on the social media. The first hashtags were dominantly conveying positive and concerning messages. By the restrictions for older people, the reaction of social spheres turned a negative language on Twitter and other social networks. Total 150 tweets, posted by individual accounts, were purposively selected from the entire sample of tweets, which matches the analysis criteria: nonymous accounts with orijinal context, nonymous accounts with reproduction of a pre-tweet, nonymous accounts in hyper-text belowed a new media sharing, and news media tweets. The algorithmic and professional social media specialists accounts are ejected from the sample by identifying allowed information of the connection. The selected data was limited to hurtful and othering comments gathered under the hashtags: due to the election of non-identified accounts and repeating messages, just 150 tweets chosen purposively. Of those ( $n=81)$ Twitter posts contain the word "65 years" $(n=69)$ posts include the word "elder/older", and the words that are used for older male relatives "dede". Additionally, $(n=18)$ of the accounts belonged to official news platforms. The device distribution that shared content accesses mainly shows mobile android and desktop devices (Figure 2), which makes us consider $\% 37,6$ of the traffic mainly android and \%24.1 Iphone, as a sum, more than half of the reactions were mobile and instant during the crisis phases (quantitative data given for exploring observation on Figure 2).

Figure 2. The distribution of devices

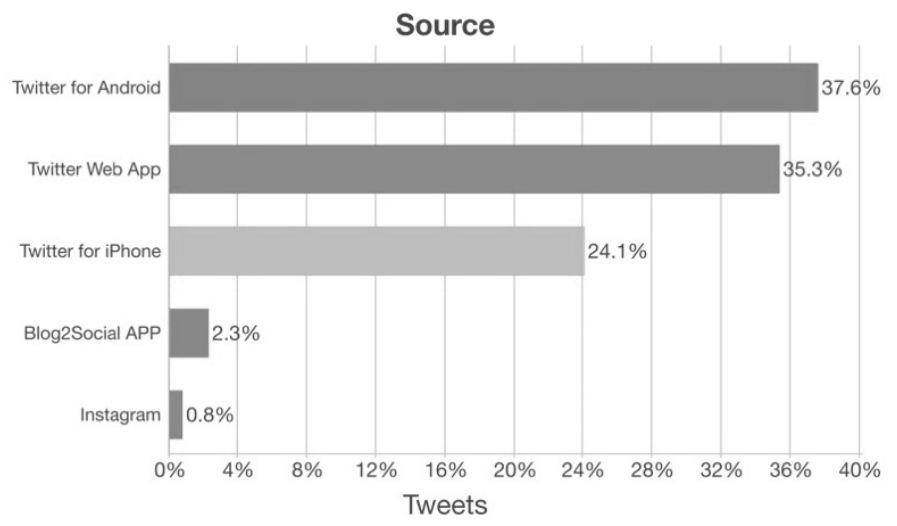

The narrowing thematic analyze is applied to the sample in two layers as visual and textual for exploring the total meaning. In language analyse, Sotomayor, Moreno and Celis (2020) study was followed as an inspiration way for constructing the approach and to provide data protection on sampled posts. In this direction, the contents classified into three thematic categories- 1 ) blaming language (blames the older age group about the contangoes of virus), 2) ironic language (joking that the tough times of older people), 3) denouncer language (young people share opinions about elder members of society)- to understand the diffused meaning of the posts. 


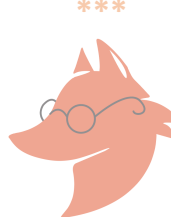

The first and dominant group of tweets $(n=65)$ refers to the blaming language category. In this category, the elderly have been accused of not complaining about the restrictions; so, they were targeted indirectly responsible for the spreading of the virus by social media users. Among the main content, hyper-texts some of the visuals, and peer photos direct the researcher to consider the relationship. The images of the public posts in this category show that the posts' visual images retweeted or copy-pasted from national and popular news channels. Many organic mobile users reproduced these news platforms context by adding their own texts. The images are to show the forbidden areas for older groups by focusing on harsh restriction implications in the public arena; the chosen visual media frame allows creating a hurtful meaning seems like the $65+$ years group are the criminal group of society and they prevent to control the spread of virus (Table 1- Sample1, 2). A strong correlation between the content and emotional response that might lead masses to participate in a chain reaction (Film Media Group, 2019) is explored. Visual content like images, videos, memes triggered emotions of individuals quicker than rational contents and led a chain reaction that probably may shape the general consent. Laying the benches on the ground, banding around the banks like a criminal scene, and the signs depicting public spaces that are prohibited for $65+$ years group install in mandatory mode, have become widespread visually involving the user in their retweets. Users were showing their reaction to 65 years group on social media by retweeting these images, both of which feeds by news organizations' accounts and shows the exclusion of $65+$ years group from the public spheres. For all that, the language of the images very powerful to transmit a meaning as if the elderly did not comply with the rules of pandemic and therefore the authorities had to take additional precautions for these areas (Table 1-Sample 3,4). It is observed that the diffusion of hurtful visuals on retweets; most of these posts claim the $65+$ years group such the rebels.

Table 1. The visual and textual blaming language examples

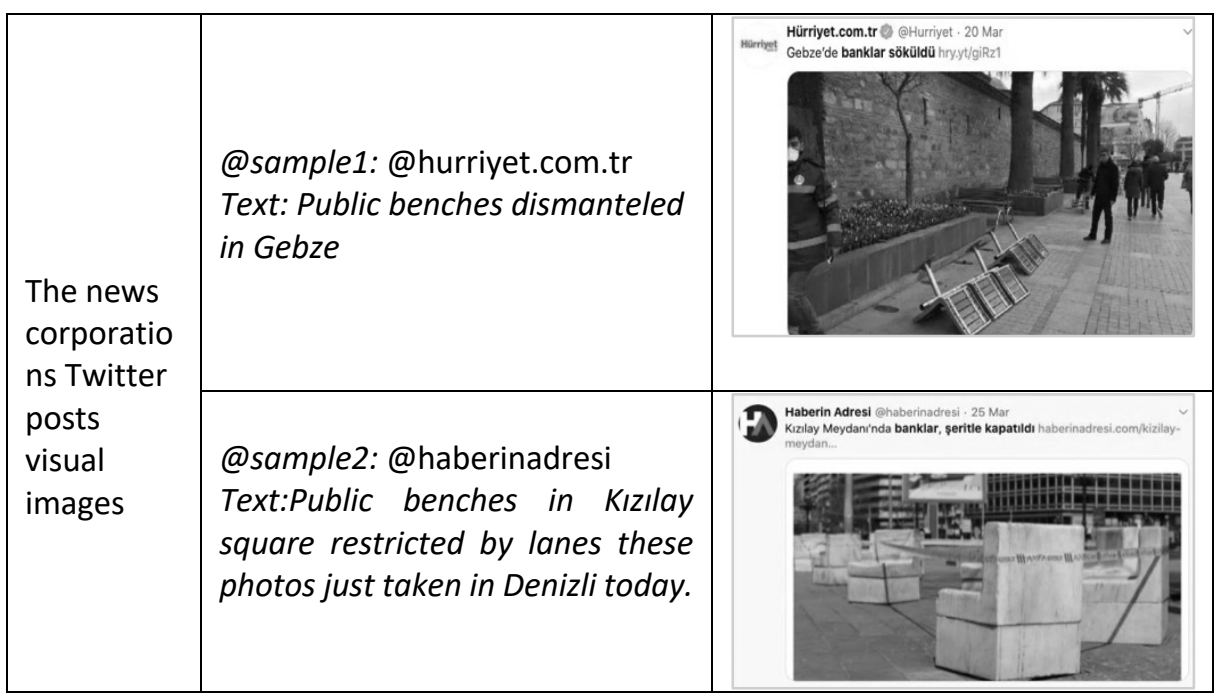




\section{MEDIAJ}

\begin{tabular}{|c|c|c|}
\hline $\begin{array}{l}\text { Blaming } \\
\text { Language } \\
\text { Visual \& }\end{array}$ & $\begin{array}{l}\text { @sample3: } \\
\text { Text:After that the public benches } \\
\text { are dismartial by city council, But } \\
\text { these men seem to have sworn to } \\
\text { sit in this square, they bring a } \\
\text { stool tomorrow. }\end{array}$ & 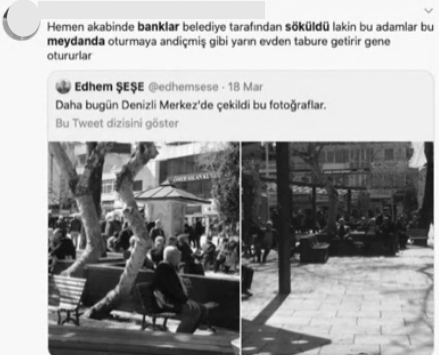 \\
\hline $\begin{array}{l}\text { Reflection } \\
\text { Sample }\end{array}$ & $\begin{array}{l}\text { @sample4 } \\
\text { Text:The public benches were } \\
\text { dismantled because of the } \\
\text { grandfathers who insisted on } \\
\text { sitting in the Edremit } \\
\text { square(announcing to city } \\
\text { authorities). }\end{array}$ & 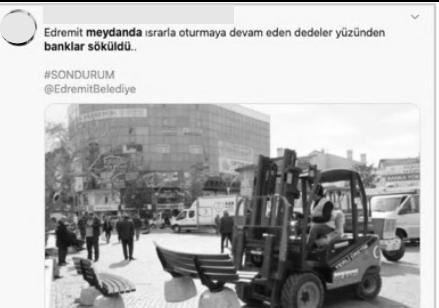 \\
\hline
\end{tabular}

More than half $(n=65)$ of the tweets contain blaming language includes official and popular news platforms accounts. Text and visual language were constructed by giving the message were very hurtful, and unethically that conveys the meaning- "They do not obey the restrictions, they were punished by authorities." In the information diffusion analysis, it is observed that the feeds of news channels affected social media floods. \%39 of the content retweeted by users included similar messages and images (numbers given for exploring observation). Some of the users report the older ones who sits on the public banks by retweeting the content to government accounts on those retweets. Most of the used language is constructed on blaming the 65 years group for public health problem. During this phase, mainstream media did not share other groups on the images and used the expressions "elders"," 65+ years group" to specify these messages. The news media messages and visuals about the restrictions for $65+$ groups and the examples what irresponsibly showed older group for following the restrictions in public area, like 65+years group trying to walk in public parks or resting on public banks, caused to turned the reaction of social media users a hurtful language. \#65 yaş and \#65yaşüstüsokağaçıkmayasağı (curfew to 65 years group) were among the first hashtags that spread hurtful language fed by videos and photographs; made the elderly on the target of social reaction as some of them can be seen in following part. The semiotic meaning of these messages created othering and spread quickly among the social media groups until becoming a trend topic across the country base.

Table 2. The visual and textual ironic language examples

\begin{tabular}{|l|l|}
\hline & \multicolumn{1}{|c|}{$\begin{array}{l}\text { @ sample 2: effect of diffusion } \\
\text { Text: Every path used to obey the } \\
\text { elders in whole country } \\
\begin{array}{l}\text { Visual \& Text } \\
\text { of } \\
\text { Social Media }\end{array}\end{array}$}
\end{tabular}




\begin{tabular}{|l|l|l|}
\hline Users & $\begin{array}{l}\text { @ sample 2 } \\
\text { Text:Take the condition serious } \\
\text { any more, your funeral pray won't } \\
\text { do by us (İmir Doğançay } \\
\text { Cemetery) }\end{array}$
\end{tabular}

The issue on 65 years group took approximately a week on both mainstream media and social media. During this phase, the ironic language includes posts $(n=37)$ as the second group messages convey fear and hurtful language. Images were manipulative, offensive, encouraged social stigma and were exclusionary. Especially, cemetery images show as a punishment to them by some users. Some other users post images that shows prisoned elders for the joke (Table 2Sample 1,2). The meaning of many messages shared in this group is observed as if you go out, you will die in an ironic language. Some of the photos shared by social media users like cemetery had been taken from the posts of national news corporations. The news framing of some national media channels caused the misinformation and othering of $65+$ years group once again by merging the general media discourse on the users' perception. It is observed that the language used in these group posts is mocking; the group over the age of 65 contains images of cemeteries and funerals that will die if they do not obey the restrictions. The expressions that make fun of this group, which the older imply that they leave to die, may cause embarrassment, fear, and anxiety for some members of older group.

It is seen that the news that may mean that this age group carries a risk and spreads the virus in the media. The experts' statements exacerbate this marginalizing discourse and much new content reproduced what will make this age group feel bad. Also, it is seen that in many different ways, mocking messages were shared stating the group over the age of 65 was taken hostage to stay at home, locked in the house, or subject to the permission of young people.

Table 3. The visual and textual denouncing language examples

\begin{tabular}{|c|c|c|}
\hline \multirow[b]{2}{*}{$\begin{array}{l}\text { Frame of News } \\
\text { Corporation on } \\
\text { Twitter } \\
\text { Visual \& Text }\end{array}$} & $\begin{array}{l}\text { Sample 1: @hurriyet.com.tr } \\
\text { Text: They warned one by one and did not } \\
\text { listen. He found a solution like this. Stay at } \\
\text { home Edirne, do not push your luck. }\end{array}$ & 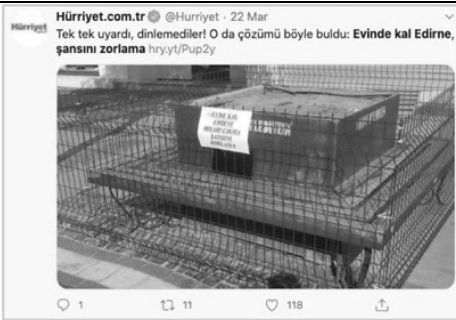 \\
\hline & $\begin{array}{l}\text { Sample 2: @turkiyegazetesi } \\
\text { Text: Despite the age of } 65 \text {, they strived to } \\
\text { withdraw money. }\end{array}$ & 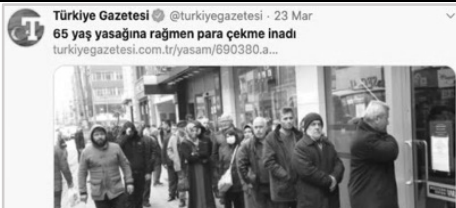 \\
\hline
\end{tabular}




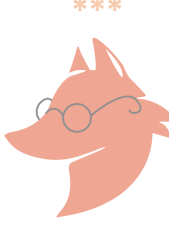

\begin{tabular}{|c|c|c|}
\hline \multirow{2}{*}{$\begin{array}{l}\text { Denouncing } \\
\text { Language of Social } \\
\text { Media Users on } \\
\text { Twitter Visual \& } \\
\text { Text }\end{array}$} & $\begin{array}{l}\text { Sample of Reflections: } 1 \\
\text { Text: They insist on do not obey rules bro! } \\
\text { Their city card cancelled, public benches } \\
\text { detached, it is forbidden to get out for their } \\
\text { age group, but they are still at outside. We } \\
\text { can't help you, then you can die (insulting } \\
\text { word) }\end{array}$ & 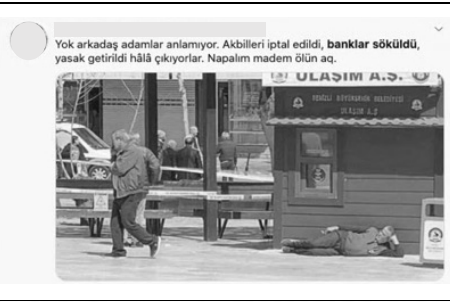 \\
\hline & $\begin{array}{l}\text { Sample of Reflections: } 2 \\
\text { Text: The public benches detached in Denizli } \\
\text { and Kırklareli due to elders who disregard } \\
\text { rules. Youngers stay at home for your health, } \\
\text { and you are at outside how type of an } \\
\text { anarchist you carry in yourself. }\end{array}$ & 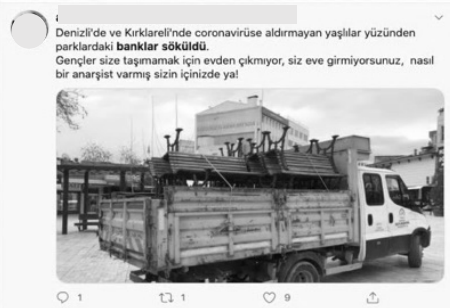 \\
\hline
\end{tabular}

Last content category is classified as denouncing language with $(n=48)$ of the tweets. These posts, shared in different versions by some media organizations, caused users to perceive the 65-age group as irresponsible and target them through social media. This group posts represents youngers' complaints about elder people and was not constructed in a respectful and insulting language. In this group, the advanced age group that goes to the bank to withdraw money and allegedly violates the rules is framed by the sharing of official news organizations (Table 3Sample 1,2). Most of users' posts were included unpleasant words, blaming claims and angry expressions through 65 years group. The most differentiated feature of this category is users' denouncements of per individual to the authorities by using official Twitter accounts on their posts. These posts dominantly include angry and insulting words. The news that is framed and circulated in this way conveys the message that it is the group over 65 that prevents the whole society from fighting the virus.

The visual images were again shared by official news organizations, where public seating areas became stiffer and banned on wires, and warnings over 65 years of age were added to them. It is observed that some users were trying to report to the individuals who hang around public spaces by tagging the Twitter accounts of the ministries and health authorities with posts containing images in a way to identify the individuals clearly (Table 4-Sample of reflections 1 , 2). For all that, the language of the images reflects a meaning like if the elderly did not comply with the rules, the authorities had to take additional precautions for these areas.

At the end of the period, the counter-reaction came from the 65+ years group. Some of them apply to public authorities officially to prevent this social media reaction. According to Coronavirus Perception Report (2020), lens of age frame shaped public opinion and led irresponsible behaviours of social media users towards 65 + years group (Coronavirus Perception Report, 2020). This shows main source news corporation should be careful about the multimeaning of their frames and its probable effects on social media users' communicative behaviour. Additionally, authorities should prevent this type of attack on society members by developing risk communication strategies and organizing public media literacy educations. 


\section{DISCUSSION \& CONCLUSION}

Health communication, which has become a discipline since the mid- twentieth century, has become more crucial especially with the complexness of healthcare applications and health information practices. This has led to an increase in the number of research and academic studies, and also different approaches emerged regarding this debate. As a result, communication is typically understood as health information transfer and perception. But during the pandemics, inequality between the social groups have shown as Butler insisted health communication is also a part of social issues. Even the health communication is a social phenomenon, most of the communication strategies are oriented to individual perspective. This study aimed to give a new topic to the health communication area by handling the othering issue over Covid-19 pandemic and older people. As it was a widen mistaken attitude around the globe that differs to country to country. Ageism studies focused health research show that social discourse usually exclude the older groups from the daily representation of social life. As previously stated in the paper, during the first pandemic phase, misinformation, uncertainty, and fear lead people create and distribute hurtful language about the older groups. As highlighted by Foucault the power of knowledge, as we focused on official news channels affected the misinformation about Covid-19 pandemic what caused to blame different groups for their so-called misbehaviour. Turkish society witnessed the othering of some group of people such as Asians, low-income status groups, healthcare workers and $65+$ years groups.

In that perspective many studies have showed us that the media discourse and social media diffusion are very effective in othering some groups of society including on issues. Habermas expresses the fundamental importance of media on generating communicative layer of public sphere which is the grand avenue of civil debate. As exemplified in the introduction section, media portray naturally had visible impact on formation of public sphere during the first extraordinary step of pandemic crisis. In this respect, we explain the general outcomes of health issues in scope of othering/ageism, and the role of media that eminently effective to shape the public opinion about health issues. According to the analysis given on the above sources, it is seen that the coronavirus named Covid-19, which is a national and international problem, affected to pave the way for othering towards individuals aged 65 and over on social media and caused communication disorders. Therefore, during the first phase of Covid-19 pandemic, it is observed that $65+$ years group were removed from social media, which is a kind of public space where common problems and goals are discussed while these groups face hurtful accusations. The insensitive media depicts what showed the exclusion of the group out of the public avenue. Besides this, the visual coding addressed the expression of criminalization. Some visual codes showed the public entrance forbidden to elders. But this framing nudged irrationally the social media users who punished 65 years by retweeting and commenting on these media frames.

Social media users denounced the elders to the official authorities by reproducing these media frames, which were ornamented by misknowledge and hurt the motivation of elders. As Foucault described, the other one refused and closed for a long time while this reflection was occurring on Twitter. The analyse findings show us the framing perspective of official news corporations have an impactful effect on tweets that are reproduced by social media users. From the starting point of the crisis to the end, it seen that new stream media is an important 


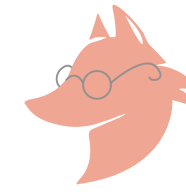

actor to create visual and textual meaning of the users. The media insist on framing $65+$ years group as rebels, caused a negative social reaction and misunderstandings among the society. Also, it is seen that in many different ways, mocking messages were shared stating that the group over the age of 65 was taken hostage to stay at home, locked in the house or subject to the permission of young people. Due to that reason, both health literacy and science literacy should be better supported by additional trains to adopt all times skills to the digital environment of communication. During the first phase of the crisis, misknowledge harmonized with fear, panic and anxiety and the reality perception was evaporated by the dominant effect of false media frames. As they showed it in other countries as Italy, Spain, the Turkish communicative layer of the public sphere was shaped with misinformation. This droves to the othering of older age group. The researchers conducted to understand the picture of disinformation during Covid-19 by Geçer proved this situation as we found familiar sharing as a result of our analysis.

Although the given information points the elder people out as the riskiest groups, the message strategy of risk communication was the crucial part of these communication strategies. Wrong constructed messages that had been published by news corporations and the comment flood on the social media lead the flood of misinformation. Therefore, as a result of misinformation flood $65+$ years group was stigmatized by social media spheres during the first phase of Covid19 in Turkey. The paper shows that media logic is the determiner of the public behaviour and asymmetrical communication strategy were implicated about epidemiological logic. The analysis also made us focus on the crucial importance of science literacy. Media members were confused to sort the reliable information from the false one during that phase. Wrong details framed the headlines, and even credible scientists denied this type of context what recalls the attractive power of false information as the studies pointed out before. In this scope, this diffusion created a new disinformation flood on Twitter about older groups. The language excluded empathizing with the disadvantaged groups, elders' life necessities were imitated, and a group of users joked with their age. We may say that this was the first moment for Turkish media, which excluded elders from society, which marginalized them by their daily life moments. When we looked at tweets, we realized some users charged the responsibility of virus infection to the 65-year-group while another group tried to denounce the elders who worked to withdraw their money from banks as criminals. These findings alarm the necessity of media and digital media literacy education for both media members and social media users. If the media members improve ethical digital literacy skills, they may help to shape more ethical users' frames. As Habermas stated, we should pay attention to preserving the inclusivity of communicative-layer, and it is more important to use logical language during crisis periods. This paper tried to draw a picture of online behaviour during the Covid-19. The public sphere's communicative layer, which formed by media power, how misknowledge formed the general wrong consensus and what was its reaction to other groups of society affected older age groups.

In conclusion, Turkey did not witness the othering of elders on media before. But normally, there is a serious representation problem of health issues in the public sphere. To widen the studies, focusing on the representation of disadvantaged groups is important to raise awareness in society. In order for understanding the effect of this language on elder groups, field research should be better conducted which may show the social practice of this misinformation flood. 


\section{MEDIA』}

Observing how they were affected by the media and social media sharing during this period can provide acquired data to build an awareness campaign for further crisis.

\section{ACKNOWLEDGEMENTS}

The pre-version of study presented vocally at the Transformations and Consequences in Society due to Covid-19 Pandemic Conference in September 2020, organized by AAB University, Kosovo. The full scope of study and full paper are not shared and published with any authorities.

\section{REFERENCES}

Altın, Z., (2020). Elderly people in Covid-19 break, Journal of Tepecik Eğitim and Araştırma Hospital (30), 49-57, doi: 10.5222/terh.2020.93723

Arendt, H. (2016). Truth and politics. İstanbul: Sel Yayıncllık

Arun, Ö., (2021). Aging in crisis periods, the elders of Turkey during Covid-19 and ageism. Journal of Ageism Studies, 4, 1-2, doi: 10.24876/senex.2021.27

Baranseli, E.S., Kaya S., K. \& Şen, M., (2016). A research on examining the interfaces experience of 60 plus social media users (60 yaş üstü sosyal medya kullanıcılarının arayüz deneyimlerinin incelenmesine yönelik bir araştırma). Anadolu University Art and Design Journal, 226-248. doi: 10.20488/sanattasarim.530160.

Barbie, E., (2007). The practice of social research. Belmont: Thomson Wadsworth.

Breen, M.J., Haynes, A. \& Devereux, E. (2006). Fear, framing and foreigners: the othering of immigrants in the Irish print media. International Journal of Critical Psychology, 16, 100-121.

Bretz, T. H., (2016). But who we? Derrida on non-human others. (Dissertation). Illionis, Loyola University Chicago, retrieved from: https://ecommons.luc.edu, (28 Feb 2021).

Buz, S., (2015). Ageism discrimination against older individuals. Electronic journal of Social Science, 14(53), 268-278, doi: 10.17755/esosder.89453

Creel, A.H., Rimal, R.N., Mkandawire, G., Böse, K. and Brown, J.W. (2011). Effects of a mass media intervention on HIV related stigma: Radio Diaries program in Malawi. Health Education Research, 26(3), 456-455, doi:10.1093/her/cyr012

Collinson, S. \& Heffernan, J.M., (2014). Modelling the effects of media during an influenza epidemic, BMC Public Health, 14(1), 376, doi: 10.1186/1471-2458-14-376.

Coronavirus Perception Research Report, Habitus Social Impact Association (March, April 2020), retrieved in 20 Dec 2020, from http://habitussosyaletki.org/raporlar/korona_v01.pdf., 


\section{MEDIA』}

Coronavirus report: media consumption and spor. (April 2020). Global Web Index. Retrieved in 12 March 2021, from www.globalwebindex.com.

Covid-19: your voices against stigma and discrimination. UNICEF (2020), retrieved in 20 August 2020, from voicesofyouth.org.

Ellis, K., (2008). Beyond the aww factor human interest profiles of Paralympians and the media navigation of physical difference and social stigma. Asia Pacific Media Educator, (19), 2335. Retrieved in 20 Dec 2020, from core.ac.uk

Ezell, J.M., Suzan, W., Friedman, S.R., Rebecca, B., Jenkins, W.D., Schneider, J., Link, B. and Pho, M.T., (2020). Stigmatize the use, not the user? Attitudes on opioid use, drug injection, treatment, and overdose prevention in rural communities. Social Science Med, 268(113470), doi: 10.1016/j.socscimed.2020.113470

Films Media Group. (2019). Battle of social networks. Films on Demand. Retrieved in 3 Sep 2020, from https://fod.infobase.com/PortalPlaylists.aspx?wID=276509\&xtid=189751.

Fiske, J. (2005). Social cognition and the normality of prejudgment. (ed). Dovidio, J.F., Glick, F. And Rudman L.A., (36-53) in On the nature of prejudes: fifty years after Allport. Oxford: Blackwell

Foucault, M. (1980). The subject of power in Dreyfus, H \& Rabinow P. (ed) Beyond structuralism and hermeneutics, (329-348). Brighton: Harvester Publishing.

Foucault, M. (2003). The birth of clinic. London: Routledge.

Gannon, K., Glover, L.\& Abel, P., (2004). Masculinity, infertility, stigma and media reports. Social Science and Medicine, 59(6), 1169-1175, doi: 10.1016/j.socscimed.2004.01.015

Geçer, E. (2020). TRT Akademi Infodemic Survey, TRT Akademi, https://trtakademi.net/wp-content/uploads/2020/08/TRT-Akademi-Infodemi-ArastirmasiRaporu.pdf

Geldenhuys, K. (2020). Disinformation spreads faster than the real threat, Safety and Secure Magazine, 113(6), retrieved in 1 May 2021, https://hdl.handle.net/10520/EJC$1 \mathrm{dbe} 60 \mathrm{c037}$

Habermas, J. (2007). The transformation of public sphere. Tanıl Bora, Mithat Sancar (trans.) Illetişim Publishing: İstanbul.

Habermas, J. (2006). Religious in the public sphere. European Journal of Philosophy,14 (1),1-25, https://doi.org/10.1111/j.1468-0378.2006.00241.x

Harmer, E. \& Lumsden, K. (2019). Introduction: online othering in K. Lumdsen and E. Harmer(eds), (pp.1-13). Online othering: exploring violence and discrimination on the Web. Basingstoke: Palgrave MacMillan. 
Heider, F. (1958). The psychology of interpersonel relations. New York: Wiley.

Herrmann, L.K., Welter, E. Berg, A.T., Peryznski, A.T. Doren, W.J.R. \& Sajatovic, M.(2016). Epilepsy misconceptions and stigma reduction: current statues in Western countries, Epilepsy behavior, 16(60), 165-173, 10.1016/j.yebeh.2016.04.003

Johnson, A. \& Enslinn, S. (2007). Language in the media: representations, identities and ideologies. London: Continuum International Publishing Group

Krippendorf, K. (1989). Content analysis. New York: Oxford University Press.

Li,Q., Med, M., Guan, X., Wu, P., Wang, X., Lei,.Z.,M., Tong, Y. , Ren, R., Leung, K.,S.,M., Lau, E.H.Y., Wong, J.Y., Xing, X., X,ang,N., Wu, Y., Li, C., Chen, Q.,Li,D., Liu, T.,B., Wenxiao,T., Chunding, C.,, Jin, L.,Yang, R., Zhou,R., Want, R., Liu,H., Yinbo, L., Liu, Y., Shao, G., Li, H., Tao, Z., Yang, Y.,, Deng, Z., Liu, B., Ma, Z., Zhang, Y., Shi, G.,Lam, T.,T.,Y., Wu, J.,T., Gao, F.,G., Cowling,B.,.., Yang, B., Leung, G.M., \& Feng, Z. (2020). Early Transmission Dynamics in Wuhan, China, of Novel Coronavirus-Infected Pneumonia. The New England Journal of Medicine, retrieved from nejm.org/doi/10.1056/NEJMoa2001316

Lippman, W. (1922). Public opinion. New York: Haurcourt Brace Jovanovich.

Markel, H. (1997). Quarantine! Eastern European Jewish immigrants and the New York City epidemics of 1982. Michigan: The John Hopkins University Press.

Meisner, B., A., (2020). Are you ok, boomer? Intensification of ageism and intergenerational tensions on social media amid COVID-19, Leisure Sciences, doi: 10.1080/01490400.2020.1773983.

Newberry, L. (2020). The pandemic has amplified ageism. 'It's open season for discrimination' against older adults. Los Angeles Times, (2020 1 May). retrieved from: https://www.latimes.com

Özdemir, E., K. (2019). The power of the Twitter to create the agenda in traditional media as a social media network: an analysis of newspapers news. Journal of International Social Research, 12(67), 915-928, doi: 10.17719/jisr.2019.3780

Özsungur, F. (2021). Strategic social work management in digital violence against women. Society and Social Services Journal, 32(2), 661-687, 10.33417/tsh.836215

Person, B., Sy, F., Holton, K., Govert, B., Liang, A., Garza, B., Gould, D., Hickson, M., McDonald, M., Meijer, C., Smith, J., Veto,L. Williams, W., Zauderer, L., and the NCIDSARS Community Outreach Team. (2004). Fear and stigma: the epidemic within the SARS outbreak. Emerging infectious diseases, 10(2), 358-363, doi:10.3201/eid1002.030750.

Population- specific HIV/ AIDS status report: Women, Toronto (2012). Public Health Agency of Canada. Retrieved from: www.canada.ca/public-health/services/hiv-aids

Reintjes, R., Das, E., Klemm, C. Richardus, J., H., Kessler, V. \& Ahmad, A. (2016). Pandemic 
public health paradox time series analysis of the H1N1epidemiology, media attention, risk perception and public reactions in 5 European countries, Plos One, 11(3), doi: 10.1371/journal.pone. 0151258 .

Rodrigez, M.G., Leskovec, J. and Schölkopf, B. (2013). Structure and dynamics of information pathways in online media. 6th International Conference on Web Search and Data Mining (WSDM 2013), Rome, Italy.

Silva, D. (2016). The othering of Muslims: discourses of radicalization in the New York Times, 1969-2014. Sociological Forum, 32(1), 133-161

Stjernsward, S. \& Glasdam, S. (2021). Solidarity and polarisation regarding Covid-19 and related risks- a thematic analysis of comments from an international survey. Social Science and Humanities Open, 4(1), 10.1016/j.ssaho.2021.100211

Sotomayor, J.M.R, Moreno, G.C. \& Celis, P. S. E. (2020). Coronavirus, ageism and Twitter: an evaluation of tweets about olders adults and Covid-19, Journal of the American Geriatrics Society,68 (8), 1661-1665, doi:10.111/jgs.16508.

Southern, R \& Hammer, E. (2019). Othering political women: online misogyny, racismand ableism towards women in public life. Online Othering, 187- 210, 10.1007/978-3-030-12633-9-8.

Sundin, O. (2015). Information litearcy in the Sweedish curriculum for compulsory schools, Nordic Journal of Digital Literacy, 10(4), 193-209

Tosun, G. (2013). Examination of postgraduate theses on twitter journalism. Etkileşim Journal, 6, 10-35, doi: 10.32739/etkilesim.2020.6.73

Turan, H. (2017). Violence on social media: the experience of other and me in scope of sense. (Sosyal medyada şiddet: sağduyunun yitiminde başkalık ve kendilik deneyimleri). Marmara University Journal of Communication, (27), 121-133.

UNESCO. (2018). Journalism, fake news and disinformation. France: UNESCO. retrieved from: en.unesco.org, (20 May 2020).

UNAIDS. (2003). Stigma and discrimination fact sheet. Geneva: UNAIDS.

We are Social. (2020). Digital in 2020. Hootsuite. (22 Jan, 2020). Retrivied from: https://wearesocial.com/digital-2020

Vosoughi, S., Roy, D. and Aral, S. (2018). The spread of true of false news online. Science, 359(6380), 1146-1151, doi: 10.1126/science.aap9559The spread of true and false news online 